\title{
Digital licence agreements and their effects on acquisitions and academic library users
}

\author{
Charles A. Masango' \\ Department of Information \& Library Studies, Centre for Information Literacy, \\ University of Cape Town, Rondebosch 770I \\ cmasango@ched.uct.ac.za
}

\begin{abstract}
Received: $28^{\text {th }}$ May 2004
Revised: $6^{\text {th }}$ December 2004

The article examines the origin of print media copyright law and the fair dealing exemptions. It analyses whether the globally accepted assumptions that the print media fair dealing exemption is appropriate in the digital environment notwithstanding that corporate rights holders of online databases have introduced licences to govern the use of digital content. The article discusses the effects on acquisitions and academic library users of incorporating the print media fair dealing exemption in the digital licensing agreements.
\end{abstract}

Key words: print media information, copyright law, fair dealing exemption, online databases, licensing agreements.

\section{Introduction}

Licence agreements are legal agreements between the suppliers of digital databases and users that have conditions on use of the databases (Keenan \& Johnston, 2000: 154). These agreements are a consequence of the birth of digital information. Some of these licences impliedly include the fair dealing exemption that was coined for print information. This fair dealing exemption allows scholars to copy and use printed works, which have not gone into the public domain without being charged of copyright infringement. The inclusion of the print fair dealing exemption in digital information is endorsed by legislative digital acts enacted by certain countries and by libraries whose common practice is to transfer the exemption to the digital environment.

The aim of this paper is to theoretically examine whether the globally accepted assumptions that the print fair dealing exemption is appropriate in the digital environment. The theoretical examination will lead to an empirical survey that will be published latter. In order to therefore analyze the assumptions, this paper first examines the origin of print media copyright law and the fair dealing exemptions. Secondly, the paper unveils how corporate rights holders have recently introduced access licences to govern digital content. The consequences of inappropriately including the fair dealing exemption in the digital environment are revealed. Finally, the paper attempts to propose changes in licensing agreements in order to accommodate the exemption in the digital realm.

\section{Crux of print media copyright law}

Prior to the emergence of digital information, copyright law governed the reproduction or copying of printed information. The appearance of the first copyright law in 1710 was the upshot of agitations from religious, ideological, and provincial printers resulting from the social, political, and economic upheavals in England at the time. These groups were agitating against the reaction of the Crown to have all printed works controlled and monopolized by the Stationers Company in London (Merges, Menell \& Lemley, 2000: 345-346).

When the first Copyright Law was promulgated in 1710, its objective was to encourage learned men to compose and write useful books (Phillips, Durie \& Karet, 1997: 5) and not to protect commercial interest. The Act allowed the purchasers of printed books to own the copies of the books they purchased (Harrison, 1971: 34). The Act revoked the printing monopoly that was dominated by the Stationers' Company, and instituted the concept of the public domain by setting limited terms for copyrighted works. This was twenty-one years copyright for books that had been produced before the promulgation of the Act (old books), and fourteen years with a possibility of an additional fourteen years for books that were produced when the Act had been promulgated (new books) (Ross, 1992: 2; Harrison, 1971: 35-36; Merges, Menell \& Lemley, 2000: 346).

The Stationers' Company refused to accept the concept of public domain. They claimed and were supported by the court ${ }^{2}$, that copyright was meant to be in perpetuity - a common law belief. After a long fight on this issue -approximately

I. Charles Masango is a lecturer in the Department of Library and Information Studies, Centre of Information Literacy at the University of Cape Town where he is also enrolled for a PhD on information ethics and policies/legislations.

2. The court held that the Copyright Act did not displace the common law rights that accepted property to be held in perpetuity. (Millar v. Taylor (I 769) 4 Burr. 2303.) 
60 years- this assertion was refuted by the House of Lords $^{3}$, as it ruled against perpetual copyright and upheld the statutory limits set in the copyright law. This battle is still being fought today as rights holders keep shifting copyright limits in order to uphold their copyright. In the United States because of Disney's copyright on Mickey Mouse, the owners were not willing to see the Mickey Mouse copyright that was to expire in 2003 enter the public domain, so they lobbied Congress extensively. In 1998, Congress passed the Copyright Term Extension Act (CTEA) extending the length of copyright to the life of the creator plus seventy rather than fifty years. Although the statute was challenged on grounds of unconstitutionality ${ }^{4}$ the challenge was lost (Harper, 200I; Sprigman, 2002). The implications are that financial corporations are constantly aware of the financial loss involved when copyrighted materials enter the public domain. They keep fighting to maintain it and are succeeding in the print environment as well as in the digital environment as we shall see.

\section{Source and development of exemptions on copyrighted works}

Notwithstanding the protection that the law accorded to publishers, following a series of court battles among publishers, the fair dealing or fair use exemption surfaced in the eighteenth century (McDonald, 1999: 3). The exemption developed before new print technology emerged. In developing the exemption, the court started by resolving issues that involved abridgements ${ }^{5}$, and established the notion of fair abridgment (Patry, 1995: 6) which is a "shortened version of a work, preparation of which does not involve rewriting or presentation in a different form" (Keenan, \& Johnston, 2000: 154). The court in clarifying abridgment, decided (Dodsley v. Kinnersley Amb. 403 (I76I) (No. 2I2) that the value of the abridged works was not supposed to affect the market value of the original work. Notwithstanding this, each case had to be decided on its own circumstances.

With the establishment of the fair dealing exemption, the content of the exemption expanded or was modified as new technologies of reproduction emerged. When the linotype and monotype technologies emerged in the nineteenth century, the fair use concept that started through the court in $1803^{6}$ and defined in 18397. (Patry, 1995: 10; 17) started being expanded. The case law fair dealing exemption was codified by statute in Britain with the Copyright Act 191।. This Act for the first time introduced "private study" fair dealing exemption when it stipulated that copying of any work for the purposes of private study, research, criticism, review, or newspaper summary was permitted (Law Reports Statutes, 1911: 183).

When the dry photocopier technology emerged in the 1940s after the microfilm technology, it allowed large-scale copying of copyrighted works, as it was cheap, quick and simple to use, the content of the fair dealing exemption was modified. The content of the British Copyright Act 19II was reviewed in the Copyright Act 1956. This act stipulated that "no fair dealing with a literary, dramatic or musical work for purposes of research or private study shall constitute an infringement if it is for purposes of criticism or review, whether of that work or of another work, and it is accompanied by a sufficient acknowledgment..." (Burke, 1956: 74/6), although it did not define or say what would tantamount to "sufficient acknowledgement". South Africa also followed suit when it reviewed the Copyright Act 1916 with the Copyright Act 1965 (Statutes of the Republic of South Africa, 1965: 1002).

In the 1960s Xerox monopolized the dry photocopier as it had the patent on the technology. With the monopoly that Xerox had on the photocopier, the company was able to sell any copied pages at whatever price they wanted to charge. When in late 1974 Xerox made an estimated I,700 patents available to its competitors after a series of lawsuits for illegally monopolizing the copier business, the advantages it enjoyed ceased. The Japanese entered and flooded the market with cheaper and better copiers than those Xerox produced. With cheaper and better copiers most libraries purchased and allowed scholars to copy all sorts of printed works and it was far cheaper for scholars to copy a book than purchase the book (Jacobson \& Hillkirk, 1986: 3-8; Feather, 1994: 176).

3. The House of Lords rejected the notion of copyright in perpetuity and upheld the statutory limits set by the Copyright Act I7IO (Donaldson v. Beckett (I774) 2 Burr. 2408).

4. The statute was challenged on two grounds. First, because the statute exceeded Congress's power under the Copyright Clause; and, second, "because the statute ran afoul of the First Amendment by substantially burdening speech without advancing any important governmental interest” (Eldred v. Ashcroft).

5. The court ruled that where books were colourfully shortened it could not be called abridgments. Fair abridgments should be called a new book because the invention, learning, and judgment of the author are in them (Gyles v. Wilcox 2 Atk. I4I, I43 (I 740) No. 130).

6. It is considered a start because in this case Lord Ellenborough did not use "fair use" but asked if the work was "used fairly" (Cary v. Kearsley 4 Esp. 168 (1803).

7. In this case "fair use" was expressly used. It was ruled that where one does not make any productive, creative use of another work but merely copies and communicates the same knowledge of the original work, the exemption would not be applied (Lewis v. Fullarton 2 Beav. 6 (1839). 
In order to reach an ingenious compromise between the owners of the copyright works and those who made copies with this technology, nations modified the contents of their copyright acts. The copyright acts of countries such as the United States, South Africa, and Britain for example, modified the contents of the fair dealing exemption in their copyright acts. Their acts hence stipulated that copying of any work for the purposes of private study, research, criticism, review, or newspaper summary was permissible provided the copied work was not used for commercial purposes (Halpern, Nard \& Port, 1999: 115; Copeling, 1978: 41-48; Laddie et al., 2000: 754). Hence, following the effects of the modern photocopier, the fair dealing exemption was moved from "acknowledgments" to refusing "commercialization" of copied works. This finally laid the rules for the fair dealing exemption that is applied today.

In print media notwithstanding the protection that the copyright act gives to owners of copyrighted works, the fair dealing exemption allows individuals to copy printed works, which have not gone into the public domain without being charged with copyright infringement. There is however no general consensus on the quantity of copies that will qualify for fair dealing. The South Africa Copyright Act 98 of 1978, section I2(I) says that there shall be no infringement of copyright by any fair dealing with a literary or musical work. Section 13 furthermore stipulates that in addition to the fair dealing allowances under section 12, "reproduction of a work shall also be permitted as prescribed by regulation, but in such a manner that the reproduction is not in conflict with a normal exploitation of the work and is not unreasonably prejudicial to the legitimate interest of the author (Copeling, 1978: 48). Notwithstanding that these sections allow copying of copyrighted works, the South African Copyright Act does not state what should be considered as a reasonable portion of copied works nor does it state how frequently copying of a document is permitted under fair dealing exemption. With this lacuna, "it is possible that a whole chapter from a long book may be considered reasonable, while in the case of a sonnet even a few lines may be held to exceed the limits of reasonability" (DALRO, [n.d.].). The consequences of the lack of clarity by the act on what a reasonable portion to be copied should be is exhibited by the South African Reprographic Rights Organization. The Dramatic, Artistic and Literary Rights Organization (DALRO) that collects copyrighted revenues for authors of copyrighted works in South Africa qualifies reasonable portion of copying under fair dealing on the basis of "totality and meaning of the work" (DALRO, [n.d.]).

Notwithstanding the unclear nature of what would and would not be accepted as fair dealing exemption, the exemption balances the rights of corporate rights holders and users of copyrighted material as it permits the copying of copyrighted material for certain purposes such as research, criticism, teaching, and under certain circumstances that will not interfere with the legitimate rights of the copyright holders (Amen, Keogh \& Wolff, 2002: 24).

The fair dealing exemption frees scholars and other users from the obligation to ask permission or to pay a fee for the copy and use of copyrighted works (Harper, 200I). In situations where scholars cannot themselves copy the information, copyright acts allow libraries to copy such information to send to users. For example, Regulation 7 of the South African Copyright Act 1978 allows libraries to "reproduce an article from a periodical issue or collection, or a reasonable portion of any other work and upon request make such copy available to a person for the sole purpose of private study or the personal or private use of the person using the work" (DALRO, [n.d.]). This affords substantial relief to many scholars especially from developing countries - as they rely on copied materials for their studies due to lack of access to original works.

\section{Emergence of digital technology}

The use of digital technology in academic libraries enables scholars to use this technology to acquire digital information that is not physically available in the library. This is germane as no academic library has been able to acquire and keep all the information or publications needed by its users (Williams, 1980: 58). Scholars get more satisfaction from digitization as it provides an increasing amount of literature that can be accessed from anywhere. Users are no longer forced to use the physical spaces of the academic library for information as they did prior to the advent of the online information system that requires browsing through shelves to obtain the information they need (Puacz, 2002:13; Richey, 2002: 17; Steve, 2001:521; Khoo, 2002).

Electronic information technology has changed the social behaviours among scholars. This as it is no more possible to copy under the fair dealing exemption in the narrower sense but at a broader sense as users have more opportunities to copy information than it is authorized because of the nature of the technology. In the digital realm users cannot only make fast copies from copyrighted works but can make copies upon copies at a faster pace without being accounted for. The digital environment offers scholars the opportunity to manipulate, alter, reformat, and erase information (Litman, 200 I: 19; Neacsu, 2002: III).

Notwithstanding the advantages provided by digital information, this information is, in practice, governed most directly by access licences (McCracken, 2004: 122) - a form of contract between library and vendor - as explained infra. The access licences permit copying, reproduction, as well as the use of the information for educational purposes if a user 
is within a group of persons authorized to use the information. Licences forbid unauthorized users as they state exactly what is being licensed, the terms of the licence, the contractual obligations to be honoured, as well as how legal terms such as assignment, termination rights, and applicable law should be handled. Licences confer no property rights on the licensee but merely give permission to do that which would otherwise be prohibited (Trisha, 1999:118-125).

With the introduction of licences, intellectual property rights holders, normally corporations rather than creators, have acquired much more control vis-à-vis end-users of information than they would normally have been granted by national copyright regimes. Corporate rights holders no longer sell copies of works, as they did throughout the centuries of dominance of print media, but rather provide access in exchange for a fee (Matheson, 2002: 157). In such a business model, of course, access can be time limited and subscribers who stop paying fees, for whatever reason, are likely to lose access altogether. When this happens, it endangers the archival role of libraries (Bowman, 200 I). Furthermore, because corporate rights holders are selling licences granting rights of access to large databases of journal titles, they are able to bundle individual titles in such a way that institutions may find themselves subscribing to long lists of journals that they neither want nor need (McCabe, 2002: 269). Libraries may be virtually coerced into accepting products, at heavily discounted subscription, that have little or no relevance to their users' needs or that may be of poor quality. Since periodicals costs constitute the major part of a library's expenditure on content, such unwanted purchases may be made at the expense of valuable, relevant or much needed materials (Chapman, 1996: 146; Rowse, 2003: I).

\section{Incentives for licensing in digital information: invalid assertions?}

The rationale for licences is that corporate rights holders believe that copies upon copies of digital information can be made at an "alarming" pace without being accounted for. Digital works can be widely "pirated" as the digital realm permits everyone to become a publisher and permits an array of possible copyright infringements such as manipulation, alteration, reformatting, and erasure that are considered "blatant information highway robbery" (Litman, 200 I: 19; Neacsu, 2002: (II). Corporate rights holders argue that licences will be able to curb unauthorized access to digital content. The corporate rights holders believe that through licences they would recover from the text copying that is allegedly costing the corporation billions per year in lost profits, jobs and government tax losses. Hence, protecting their information through licensing agreements would increase their chances to recuperate more revenues and increase their incentives to create more (Rogers, 2000; Sprigman, 2002).

Following the advantages that licences offer, corporate rights holders believe that the current legal rules of licences governing digital information are ideal and should not be changed for untried rules (Ginsburg, 1994: 2559).

The reasons raised by publishers for imposing licences on digital information are somewhat questionable. Although the assertion that digital technology permits easy copying is true, it is not certain that licensing agreements will limit the rate of digital copying. Today, in the print environment, copying persists notwithstanding certain measures taken by publishers. Some 500000 pages of printed works are photocopied every minute throughout the world in spite of the role played by the Reproductive Rights Organization (RRO) that is meant to collect fees for publishers (Publishers' Association of South Africa (PASA, [n.d.]). Thus it is reasonable to argue that the copying of digital information is not caused by the technology of digitization, but because those with specialist needs, such as acquisitions librarians and scholars, are not given the opportunity to access and evaluate digital information to judge if it meets their requirements (Stallabrass, 2002: 143).

Hence, to address the aspect of copying, publishers could institute the "exposure effect" on digital works. The exposure effect is a form of advertising or sampling of the digital information. Where advertisements and samples are available, it might lead to greater sales of legitimate versions of the copyrighted works. This as some acquisitions librarians and users of pirated works, for instance, might find themselves wanting the manuals and technical support that will only be found in authorized libraries and users of the work (Liebowitz, 2002: 4).

With regard to the contested aspect of lost revenue, publishers can resolve this by embarking on the "network effect". This is by corporate rights holders charging higher prices on their digital information based on the number of individuals who would use the information. For example, if the corporate rights holders are told that the number of individuals to use the information is 10 , and the price for 10 persons accessing the information is RI5,000, they can charge RI6,000 for the information. The extra RI,000 is charged for the unforeseen user who was not considered when the contract was negotiated. Also, the corporate rights holders can decide not to charge for the information at the beginning and only charge at the end of an academic year or semester. Where this model is adopted the measurement upon which the charges would be calculated will be the number of hits registered on the database. In cases where this procedure is followed, it will allow corporate rights holders to capture part, all, or more of the revenue than might have been appropriate through ordinary sales of their services. Through these methods any user who uses the information pays the corporate rights holders (Takeyama, 1994: 155; Liebowitz, 2002: 6). 
The network and exposure effects increase the amount of the value received by users of the works, allowing corporate rights holders to generate more revenues with constant or even somewhat reduced levels of uncertainty. This as corporate rights holders may gain the largest individual market share by developing and freely sharing new technology rather than seeking to penetrate a market with a proprietary venture (Liebowitz, 2002: 4-6; Updegrove, 2002).

With regard to the aspect of incentives for more creative work as the original copyright law in 1710 had envisaged, there are no certainties that an increase in revenue would lead to an increase in creativity. Various creators may have different motives for creativity. In the ancient times, certain authors as well as monks and scholars in the middle ages, created without copyright protection (Liebowitz, 2002: 3; Landes \& Posner, 1989). In 200I, during the creation of the Budapest Open Access Initiative, scientists and scholars agreed to publish the fruits of their research in scholarly journal without payment for the sake of inquiry and knowledge. They agreed not to invoke copyright to restrict access to and use of their published works (Fishman, 2002: 18).

\section{Legislative protection of digital information}

In order to protect corporate rights holders' digital content, some nations have enacted new legislative acts. The United States has promulgated the Digital Millennium Copyright Act (DMCA) of 1998 and the Australians the Copyright Amendment (Digital Agenda) Act of 2000. Although these nations have promulgated these acts, these acts do not contain new clauses that will enable users of digital information to fairly use the information without being accused of infringement. These acts have simply adopted the contents of the print fair dealing exemption into the digital environment with circumvention clauses that make it a crime for any user who wants to copy digital information. In the United States, the Digital Millennium Copyright Act (DMCA) 1998 that was promulgated to govern digital works incorporated the fair dealing exemption in section I20I(I)(c) (The Digital Millennium Copyright Act 1998). The Australian Copyright Amendment (Digital Agenda) Act 2000 expressly stipulates that the fair dealing that exists in the print environment should be applied in the digital realm (Lahore, 1996: 5/275).

Generally, the implementation of licences that implicitly includes print media fair dealing exemption, or the adaptation of the print media fair dealing by the new digital acts as well as the common practice of libraries to transfer the print media fair dealing exemption to the digital environment are inappropriate as we shall see.

\section{Flaws and consequences of licensing agreements on scholarly communication}

Perpetual copyright has been an implicit or explicit goal of corporate rights holders (publishers and vendors) from the very beginnings in the $18^{\text {th }}$ century to date. The advent of the licensed database on online digital databases has effectively provided the corporate vendor with a mechanism that ensures that the most useful forms of texts will in practice never fall into the public domain. The cherry on the top is that the question of the copyright term is not even a self-evident part of the licensing problem.

The constant extension throughout history of the copyright term, often against strong resistance, culminated in the 1998 Sonny Bono Copyright Term Extension Act, shifting the terms of copyright from a lifetime plus fifty years to a lifetime plus seventy years. But this has its root in the fight against the Copyright Act of 17/0,and the unexpected enforcement by the House of Lords in 1774 of a statutory limit to copyright protection. This decision paved the way for the creation of the public domain of information, to be used without the need for permission, payment of a fee, or an appeal to the fair dealing exemption.

Licensing agreements do not, of course, specify when, if ever, their contents as a constantly renewable collective work might be expected to fall into the public domain. They are not expected to do this, and they don't. As long as the contracts are renewed, users will be obliged by contract law to abide by them. This is severely inhibiting, since it implies that access to the scholarly record in its technically most convenient form will always have to be paid for.

The vacuum created by licensing agreements in delimiting the rights of scholars inhibits the opportunity for scholars to freely access these databases at any given time in history. Furthermore, the non-compliance by licences to the public domain concept is an indication that publishers of these databases have succeeded to establish for themselves a right in perpetuity that they are struggling to achieve in the print media environment. This is contrary to the statutory limits to copyright works that established exceptions to copyright infringement (Lindsay, 2002: 7).

Licensing agreements do not expressly encompass the fair dealing exemption. The implied provisions of the fair dealing exemption in licensing agreements not only help to confuse users of information but also the acquisition librarians who acquire the information for the user. For example, where a licensing agreement expressly accepts copying, the agreement does not clarify the law that governs such copies when the information is transformed into hard copy. Following the rules that govern the two formats of information, although copyright law applies to both digital content and print information, licensing agreements governs digital content and not print information. In instances where the licensing 
agreement permits the copying of digital works but fails to sketch the border where the licensing terms discontinue and the copyright law commences when digital content is transformed to print, the acquisition librarians and the users who make copies are confused. The librarians cannot inform the users as to the limit of any agreement as they do not know. In the print environment users are aware that once a copy of a work is made, the fair dealing exemption applies. In cases where information is converted from one format to another, as is the case with digitization, users and acquisition librarians of digital information cannot differentiate when licensing agreements would apply and where it ceases to apply.

The vagueness of licensing agreements to clarify the limits of their existence, places librarians in difficulties when they have to send information that can only be found in digital format through Inter Library Loans (ILL) as some licences such as ScienceDirect permit ILL (ScienceDirect Subscriber Licence, 1998). Most of the librarians refuse to send information that can only be found in electronic databases through ILL on the premise that the requester of the information is an unauthorized person to use such information. This lack of clarity in licensing agreements inhibits users from accessing digital information sources and services thereby inhibiting scholarship, as those who are not authorized to access the information cannot use it.

However, scholars -according to an empirical survey ${ }^{8}$ - who respect the intellectual property of others, try to clarify this scenario by arguing that once digital information is copied on paper, only the copyright law prevails and the fair dealing exemption as it is applied in print media prevails. This interpretation is however questionable as licensing agreements do not provide this distinction.

\section{Flaws in relocation by legislature and licences of print fair dealing exemption in the digital environment}

Notwithstanding that licensing agreements and legislations imply and expressly accommodate print fair dealing exemption in the digital realm, the question we should be asking ourselves is whether the print fair dealing exemption is suitable in the digital environment.

The introduction of a new mechanism in the form of licences to govern digital information without analogy for the fair dealing exemption in the digital realm, seems unsuitable because the types of reproductions that are automatically carried out in the digital environment are not similar to those carried out in the print environment. When the fair dealing exemption was blueprinted it never took into account that the Internet user's personal computer had to make a Random Access Memory (RAM) or cache copy of the HyperText Markup Language (HTML) and Uniform Resource Locators (URL) to display the material (Litman, 200I: 26-28). In a case in court (Microsoft v. Business Boost 49 IPR 573 (2000), it was held that loading material into a computer's RAM was a reproduction of a substantial part of the computer program. Furthermore, when the fair dealing exemption was being shaped it did not foresee that viewing or accessing material online would involve a substantial reproduction of the material (McDonald, 1999: I0; Litman, 200I: 9I-92). The fact that these types of reproductions were never considered when the fair dealing exemptions were being developed in the print environment is testimony that applying the print media fair dealing exemption in the digital environment inhibits information sources and services from users. This as browsing information on the computer screen is reproduction.

The print fair dealing exemption seems unsuitable in the digital realm, as there is no permanent transfer of property in the digital realm. In print media, ownership transfer of copyrighted works is permitted as the copyright law that embodies the fair dealing exemption embraces the common law of property that allows a purchaser of a copyrighted work to own such a work. In the digital realm, ownership of copyrighted works is not permitted as publishers only sell access to their work to libraries and users that are the principal subscribers of the works. Since the libraries do not own the copyrighted works, the libraries cannot lend, give the property out as a gift, or resell the property as purchasers of printed works are allowed to do without the publisher's permission (Miller \& Feigenbaum [n.d.]; Halpern, Nard \& Port, 1999:79). As libraries are restrained by the licensing agreements from performing these activities, it seems reasonable for the fair dealing exemption to be revisited, to clarify matters that involve lending of digital works to other institutions.

Also, the print fair dealing exemption seems unsuitable in the digital realm because when the exemption was being designed it warranted that both the reproduced and original text from where the reproduction was done had to be in a physical format. This was germane as there were no possibilities for the early technologies of reproduction to reproduce or copy texts that were not in hard copies. This is however contrary in the digital environment as digital works can be converted into hard copy text and vice versa.

The incorporation of the same fair dealing exemption that exists in the print environment to the digital environment seems incongruous, as the fair dealing exemption that is applied in the print environment has no clear definition. The copyright acts of most nations do not define the fair dealing exemption. Section I2(I) of the South African Copyright Act 98 of 1978 for example, does not offer a definition of fair dealing (Copeling, 1978: 4I). Similarly, in the United Kingdom

8. Empirical survey on licences for digital information conducted as part fulfillment of my PhD investigation. 
and the United States Copyright Act 1976, fair dealing or fair use as it is referred to in the United States is not defined (Laddie, et al., 2000: 754; Nimmer, 1985: 368). In Australia, although the Copyright Act 1968 sets out an inclusive list in section 40(2) of matters to which regard is to be had in determining fair dealing, there is insufficient guidance as to what in a specific instance will amount to fair dealing by way of reproduction. The Act does not define what an exclusive right is or what would constitute reproduction. The Act merely uses exclusive right in the sense of a right belonging to one person or entity, or class of persons or entities (Sterling \& Hart, 198I: 20).

\section{Conclusion}

Following the evolution of information it seems incorrect to apply without modification the fair dealing exemption meant for print media in the digital environment. Copyright fair dealing exemption was created to deal with the products of the printing press (Hofman, 1999: 12). This was to take into account the various new forms of mechanical reproduction that were proliferating print media information at that time (Miller \& Feigenbaum, [n.d.]. Logically, the content of the fair dealing exemption has to evolve with the emergence of the new technology of digitization as it evolved when new reproductive mechanisms emerged in the print environment.

In the nineteenth century when the stereotype, the lithograph, the linotype and monotype technologies were invented, the content of the fair dealing exemption stipulated that fair dealing was permitted for the purposes of private study, research, criticism, review, or newspaper summary. In the 1930s when the microfilm technology provided a potentially cheap means of copying rare research materials and books long in the public domain, and the dry photocopier technology made it relatively easier to copy printed works, the content of the fair dealing exemption was modified. The content stipulated that fair dealing was permitted in the copying of literary, dramatic or musical works provided there was acknowledgment. Furthermore, when the photocopier technology was massively used in the latter part of the twentieth century, as it provided a much cheaper and easier way of copying printed works, the content of the fair dealing exemption was changed. The content stipulated that fair dealing was permitted on copyrighted works for educational purposes provided it did not affect the potential market for or value of the copyrighted work.

Notwithstanding that the fair dealing exemption is still not defined in the environment for which it was molded, its content has to be changed if it is to satisfy the digital environment. In changing the content in the digital realm, the licensing agreements have to sketch the border where the licensing terms discontinue and only the copyright law commences when copying from digital format to print format is done. Furthermore, the licensing agreements have to clarify the term "reproduction". In clarifying reproduction, serious consideration has to be given to the types of reproductions that are automatically carried out in the digital environment.

The vacuum created by both licensing agreements, and legislative texts in not addressing these issues inhibits scholars from freely accessing and using digital information sources and services at a given period. Not until these issues are resolved can we see scholars using this information to accomplish the objective of the 17I0 copyright law - a law that was to encourage learned men [sic] to compose and write useful books.

\section{Acknowledgment}

This article was presented at the $3^{\text {rd }}$ Southern African Acquisitions Conference, 17-19 May 2004, CSIR Conference Centre, Pretoria.

\section{References}

Amen, Kathleen., Keogh, Trish., \& Wolff, Necia. 2002. Digital copyright: A tale of Domestic discord, presented in three Acts. Computer in Libraries 22(5): 22-27.

Bowman, Lisa. 200I. Library "radicals" targeted in latest copyright battles. [Online]. Available: http://www2.mrbrklyn.com/ resources/cnet-library.html [2004, June 28].

Burke, John. 1956. Current law statutes annotated 1956. London: Sweet \& Maxwell Limited.

Chapman, Liz. 1996. Developing site licensing with particular reference to the National United Kingdom initiative. In Advances in Librarianship. 20: 123-I 49.

Copeling, A.J.C. 1978. Copyright and the Act of 1978. Durban: ButterWorths.

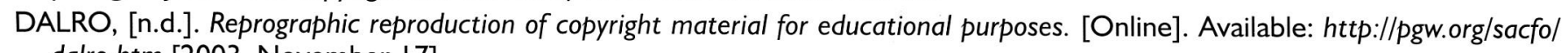
dalro.htm [2003, November 17].

The Digital Millennium Copyright Act of 1998. 1998. The Digital Millennium Copyright Act of 1998: Copyright Office Summary. Pub. L. No. 105-304, II 2 Stat. 2860 (Oct. 28, 1998). [Electronic]. Available: http://www.loc.gov/copyright/legislation/dmca.pdf [2002, September 04].

Feather, John. 1994. Publishing, piracy and politics: An historical study of copyright in Britain. London: Mansell Publishing.

Fishman, Becky. 2002. Open access in scientific publishing-handing back the power. Bellagio publishing network newsletter: an occasional publication concerning publishing and book development. 30: 17-19. 
Ginsburg, Jane C. 1994. Four reasons and a paradox: the manifest superiority of copyright over Sui Generis protection of computer software. Columbia law review. 94: 2559. [Electronic]. Available: http://www.law.cornell.edu/commentary/intelpro/ gns94txt.htm [2003, April 02].

Halpern, Sheldon W.; Nard, Craig Allen \& Port, Kenneth L. 1999. Fundamentals of United States intellectual property law: Copyright, patent, and trademark. The Hague: Kluwer Law International.

Harper, Georgia. 200I. Will we need fair use in the twenty-first century? [Online]. Available: http://www.utsystem.edu/OGC/ IntellectualProperty/fair use.htm [2003, August 25].

Harrison, J. Clement. 1971. Copyright history. Encyclopaedia of Library \& Information Science. New York: Marcel Dekker. 6:3336.

Hofman, Julien. 1999. Cyberlaw: A guide for South Africans doing business online. Cape Town: Ampersand Press.

Jacobson, Gary \& Hillkirk, John. 1986. Xerox American Samurai: the behind-the-scenes story of how a corporate giant beat the Japanese at their own game. New York: Macmillan Publishing Company.

Keenan, Stella \& Johnston, Colin. 2000. Concise dictionary of library and information science. $2^{\text {nd }}$. ed. London: Bowker Saur.

Khoo, Michael. 2002. Privacy in the "library without wall": Library practice in an age of digital content. Library and Information science Research Electronic Journal. I2(I). [Electronic]. Available: http://libres.curtin.edu.au/libres/2nI [2003, April 9].

Laddie, Hugh et al., 2000. The modern law of copyright and designs. $3^{\text {rd }}$. ed. London: Butterworths.

Lahore, James. 1996. Digital Agenda-The Copyright Amendment (Digital Agenda) Act 2000 Sydney, Australia: Butterworths.

Landes, W.M. \& Posner, R.A. 1989. An economic analysis of copyright law. Journal of legal studies. 18. 325-363. [Electronic]. Available: $h$ ttp://cyber.law.harvard.edu/ipcoop/89landl.html [2002, December 19].

Law Reports Statutes. 1911. Copyright Act, 1911. London: Eyre \& Spottiswoode. XLIX: 182-205.

Liebowitz, Stan. 2002. Policing pirates in the networked age. Policy analysis. 438. [Electronic]. Available: MAP:// mail.uct.ac.za?fetch $>$ UID $>$ Inbox/;section $=2 \&$ part $=1.2$ [2002, June 29].

Lindsay, David. 2002. The law and economics of copyright, contract and mass market licences: Research paper prepared for the Centre for Copyright Studies Ltd. [Online]. Available: http://www.copyright.com.au/reports\%20\&\%20papers/ IssuesPaper_Lindsay.pdf [2002, November 04].

Litman, Jessica. 200I. Digital Copyright. New York: Prometheus.

Matheson, Scott. 2002. Access versus ownership: A changing model of intellectual property. In Law library collection development in the digital age. New York: Haworth. 2I (2/3and 4): I53-I76.

McCabe, Mark J. 2002. Journal pricing and mergers: A portfolio approach. American Economic Review. 92(I): 259-269.

McCracken, Richard. 2004. Agreements, user licences and codes of practice. In staying legal: a guide to issues and practice affecting the library, information and publishing sectors. $2^{\text {nd }}$ ed. Edited by Chris Armstrong \& Laurence W. Bebbington. London: Facet Publishing. 122-139.

McDonald, lan. 1999. Copyright in the new communication: Balancing protection and access. Australia: Centre for Copyright Studies.

Merges, Robert P.; Menell, Peter S. \& Lemley, Mark A. 2000. Intellectual property in the new technological age. $2^{\text {nd. }}$ ed. New York: Aspen Law \& Business.

Miller, Ernest. \& Feigenbaum, Joan. [n.d.]. Taking the copy out of copyright. [Online]. Available: http://cs-www.cs.yale.edu/homes/jf/ MF.pdf [2002, May 24].

Neacsu, E. Dana. 2002. Legal scholarship and digital publishing: Has anything changed in the way we do legal research? In Law library collection development in the digital age. New York: Haworth Information Press. 21(2/3and 4): 105-I22.

Nimmer, Melville B. 1985. Cases and materials on copyright and other aspects of entertainment litigation including unfair competition, defamation, privacy illustrated. $3^{\text {rd }}$. ed. Minnesota: West Publishing Co.

Patry, William F. 1995. The fair use privilege in copyright law. $2^{\text {nd }}$ ed. Washington, D.C.: The Bureau of National Affairs.

Phillips, Jeremy; Durie, Robyn \& Karet, lan. 1997. Whale on copyright. $5^{\text {th. }}$ ed. London: Sweet \& Maxwell.

Puacz, Jeanne. Holba. 2002. Catching (and keeping) e-patrons. Computers in libraries 22(I): I2-I4, 7I-72.

Publishers' Association of South Africa2 (PASA). [n.d]. What effect does unauthorized photocopying have on the publishing industry? [Online]. Available: http://www.publishsa.co.za/copyl.htm [2003, November 04].

Richey, Cynthia. K. 2002. Molding effective Internet policies. Computers in Libraries. 22(6): 16-21.

Rogers, Paul. 2000. Title software piracy: What are the issues? [Online]. Available: http://www.newi.ac.uk/poultonj/CISE/ Software00.html [2002, November 06].

Ross, Trevor. 1992. Copyright and the invention of tradition. Eighteenth-Century Studies. 26(I): I-27.

Rowse, Mark. 2003. The consortium site licence: A sustainable model? Libri. 53(I): I-I0.

ScienceDirect Subscriber Licence. 1998. [Online]. Available: http://www.griffith.edu.au/ins/collections/ejournal/elsevier.pdf [2004, May 24].

Sprigman, Chris. 2002. The mouse that ate the public domain: Disney, the Copyright Term Extension Act, And Eldred v. Ashcroft. FindLaw's Legal Commentary, Tuesday, March 05, 2002. [Electronic]. Available: http://writ.news.findlaw.com/scripts/ printer_friendly.pl?page =/commentary/20020305_sprigman.html [2002, May 06].

Stallabrass, Julian. 2002. Digital commons. New left review 15:141-146.

Statutes of the Republic of South Africa. 1965. Statutes of the Republic of South Africa with alphabetical table of contents and table of laws, etc., repealed or amended by these statutes Part I-Acts 1-65. Pretoria: Cape \& Transvaal Printer, Cape Town. 9961058.

Sterling, J.A.L. \& Hart, Geoffrey E. 198I. Copyright law in Australia and the rights of performers, authors and composers in the Pacific Region. Sydney: Legal Books Pty Ltd.

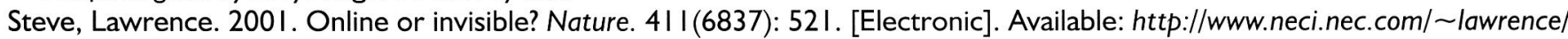
papers/online-nature0I/ [2002, May 22]. 
Takeyama, Lisa. N. 1994. The welfare implications of unauthorized reproduction of Intellectual Property in the presence of demand network externalities. Journal of Industrial Economics. 42: I55-I66.

Trisha, L Davis. 1999. Legal issues: The negotiator's perspective for getting to heart of the licence. In Virtually yours models for managing electronic resources and services. Edited by Peggy Johnson and Bonnie MacEwan. Chicago: American Library Association.

Updegrove, Andrew. 2002. The year of the consortium. [Online]. Available: http://gu.com/publications/consortium/I.shtml [2002, July [2].

Williams, Gorden.R. 1980. The function and methods of libraries in diffusion of knowledge. In The role of libraries in the growth of knowledge: Proceedings of the fortieth conference of the graduate library school, May 18-199, 1979. Chicago: The University of Chicago Press. 58-75. 